\title{
Papio papio
}

National Cancer Institute

\section{Source}

National Cancer Institute. Papio papio. NCI Thesaurus. Code C161028.

The baboon species, Papio papio. 